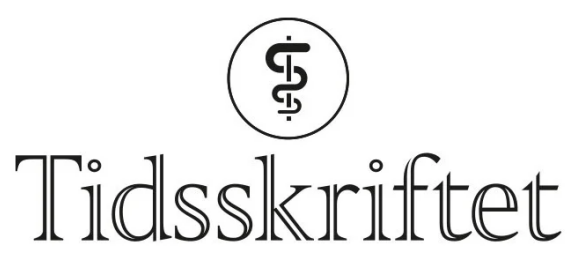

DEN NORSKE LEGEFORENING

\title{
A. Fedøy svarer
}

\author{
KOMMENTAR
}

\section{ARNSTEIN FED $\varnothing Y$}

arnstein.fedoy@cgr.no

Arnstein Fedøy er faglig leder i Consult gruppen AS og styremedlem i Brannfaglig Fellesorganisasjon. Forfatteren har ikke oppgitt noen interessekonflikter.

Takker for raske tilbakemeldingen på artikkelen fra FHI og erkjennelsen av risikoen.

Som styremedlem i Brannfaglig Fellesorganisasjon (BFO) jobber jeg mye opp mot myndighetene og rask reaksjon og erkjennelse, er ikke vi er vant med. At FHI svarer så raskt og at Tidsskriftet tok inn denne artikkelen, må berømmes.

Det at FHI er enig i budskapet om at lagring og bruk fortjener mer oppmerksomhet, fortjener honnør. Det er kun ved erkjennelse av et problem/utfordring, at det er villighet til å gjøre noe med dette. At risiko rundt dette skal tydeliggjøres, vil gange hele helsetjenesten.

I etterkant av publiseringen av artikkelen, har jeg fått bekymringseposter på andre plassering av dispenser, som inne i heis. Her har man et lukket rom uten noe slokkeapparat, som i verste fall kan stoppe opp med sengeliggende pasienter. Hvordan er det tenkt at en evakuering skal skje fra et slikt rom? Hvor lang tid har man på seg, før kritisk skader må påregnes og når er dødsfall sannsynlig?

Mitt og BFO sitt anliggende er det tilsynelatende manglende forholdet Helse Norge har til brann og risiko. BFO vil utfordre Helse- og omsorgsdepartementet med aktuelle underliggende etater å ikke fragmentere brann, eksplosjon og sikkerhet inn i mange veiledere, men heller lage en felles veiledning tilpasset Helse Norge. Det er etter vår mening kun en samlet forståelse for dette området som kan løse det det store spørsmålet som artikkelen med den underliggende rapporten stiller, hvorfor oppdager ikke virksomhetene betydelig risiko? Jeg tror ikke at det skyldes evnene, men er det vilje til reell endring i utdanning, opplæring og praksis?

Oppfordrer alle med interesse og som arbeid med brann og sikkerhet i Helse Norge, å følge med på BFO sin nettavis www.brennaktuelt.no for relevant informasjon.

Publisert: 16. august 2021. Tidsskr Nor Legeforen. DOI: 10.4045/tidsskr.21.0524

(C) Tidsskrift for Den norske legeforening 2023. Lastet ned fra tidsskriftet.no 26. april 2023. 